\title{
Cinsiyet ve Saldırganlık İlişkisi: Görgül ve Kuramsal Çalışmalara Güncel Bir Bakış
}

\author{
H. Andaç Demirtaş-Madran \\ Başkent Üniversitesi
}

\begin{abstract}
Özet
Kuşkusuz saldırganlıkla ilişkisi en çok sorgulanan değişken cinsiyettir. Erkeklerin kadınlardan daha saldırgan olduğu yönündeki evrensel yaygınlığa sahip olan inanç birçok araştırmayla doğrulanmışsa da, iki değişken arasındaki ilişkinin bu denli basit olmadığı açıktır. Bu gözden geçirme yazısında temel amaç, güncel araştırmalar ve meta-analiz çalışmaları temelinde cinsiyet ve saldırganlık ilişkisini ele alıp irdelemektir. Çalışmada, bunun yanında, iki değişken arasındaki ilişkiyi konu alan araştırma bulguları temel kuramsal bakış açıları çerçevesinde değerlendirilecek, gözlenen cinsiyet farklılıklarının genetik, evrimsel, biyolojik, hormonal, sosyal öğrenmeye ve sosyal rollere dayalı kökenleri tartışılacaktır.
\end{abstract}

Anahtar kelimeler: Saldırganlık, cinsiyet, toplumsal cinsiyet, şiddet, evrim, genetik

\begin{abstract}
We can define aggression as a behaviour that is expressed with an intent to harm, injure, or exploit another person. Undoubtedly, gender is the most researched variable in the relationship with aggression. Although the universal belief of "men are more aggressive (especially physically) than women" has been confirmed by many studies, it is clear that the relationship between the two variables is not so simple. In this review, the relationship between gender and aggression will be examined based on current researches and meta-analysis. At first, the definitions of aggression will be emphasized. Then, the relationship between the two variables will be analyzed in light of current research findings. Finally, these findings will be evaluated and discussed within the main theoretical perspectives.
\end{abstract}

Keywords: Aggression, sex, gender, violence, evaluation, genetics

Yazışma Adresi: Prof. Dr. H. Andaç Demirtaş-Madran, Başkent Üniversitesi, İletişim Fakültesi, Bağlıca Kampüsü Fatih Sultan Mahallesi Eskişehir Yolu 18.km 06790 Etimesgut / Ankara

E-posta: andac@baskent.edu.tr

Gönderim Tarihi: 18.03.2019

Kabul Tarihi: 12.11.2019 
Uygarlık tarihi boyunca tüm kültürlerde saldırganlığın ve şiddet olaylarının azalması için büyük çaba harcanmış olmasına karşın, insanın saldırganlık eğiliminde bir azalma görülmemiş ve hatta, yeni saldırganlık türleri kendini göstermeye başlamıştır (örn., siber zorbalık). 1950-2000 yılları arasında saldırganlığa ve şiddete ilişkin tutumlar arasında büyük bir farklılık bulunmaktadır (Tremblay ve Nagin, 2005). Yarım yüzyıl kadar önce öğretmenlerin bir soruyu yanlış yanıtladığ için öğrencisini fiziksel yönden cezalandırması olağan karşılanırken, günümüzde bu bir suç olarak değerlendirilmektedir. Artık birçok ülkede fiziksel saldırganlığa "sıfır tolerans" bir ilke olarak benimsenmektedir. Çatışmaları çözmek için fiziksel saldırganlığa başvurmamak adeta uygar insan olmanın temel koşulu olarak kabul edilir olmuştur.

Saldırganlık, bugüne dek, davranışın gözle görünürlüğü, ortaya çıkan sonuç ve davranışın altında yatan niyet gibi farklı ölçütler temelinde birçok farklı şekilde tanımlanmıştır. Uzun yıllar boyunca, tanımlamalar Davranışçı Yaklaşımın (Bandura, 1973; Shaffer, 2009) izinde, davranışın sonucu ve gözle görünürlüğü (kurbanın zarar görüp görmediği) temelinde yapılmış, ancak bu yönelim, bu durumda saldırgan olmayan davranışların saldırgan (arkadaşına yanlışlıkla çarpan çocuğun onun yaralanmasına yol açması), saldırgan olanların da (cinayete teşebbüs eden birinin ateş edip hedefi iskalaması) masum birer davranış gibi değerlendirilmesine yol açtığ 1 için büyük eleştiriler almıştır. Son yıllarda, asıl belirleyici ölçütün davranışın altında yatan "niyet" olması gerektiği üzerinde bir uzlaşı sağlanmıştır. Saldırganlık, bu doğrultuda "bir bireye zarar vermek, onu yaralamak ya da sömürmek niyetiyle gerçekleştirilen davranış" olarak tanımlanabilir (Polascheck, Collie ve Walkey, 2004, s. 485).

Sonuçları, belirleyicileri ve dişavurum şekilleri açısından özenle ele alınması gereken bir olgu olan saldırganlık, dinamik ve çok yönlü bir sosyal-duygusal süreçtir (Gendreau ve Archer, 2005; s.29). Üzerine birçok kuram geliştirilmiş, nedenlerinden tetikleyicilerine, türlerinden gelişimi ve sağaltımına kadar konuyu irdeleyen çok sayıda araştırma gerçekleştirilmiştir.

Bunun yanında, kadınlarla erkekler arasındaki farkl1lıklar da her zaman ilgi çeken bir konu olagelmiştir. Araştırmalar kadınlarla erkekler arasındaki en belirgin farklılığın saldırganlık olduğunu göstermektedir (örn., Eisner ve Malti, 2015; Marcus, 2017). Literatüre bakıldığında, birçok farklı yaklaşım rehberliğinde bu iki değişken arasındaki ilişkiyi araştıran çalışmalar yürütüldüğü görülmektedir(örn., Björkqvist ve Niemela, 1992; Crick ve Grotpeter, 1995; Galen ve Underwood, 1997). Bu gözden geçirme yazısında temel amaç, saldırganlık ve cinsiyet ilişkisini konu alan araştırmaların bulgularını yaygın kabul gören kuramsal yaklaşımlar 1şı̆̆ında ele almak ve güncel meta-analizler temelinde iki değişken arasındaki ilişkiyi irdelemektir.

\section{Cinsiyet ve Saldırganlık İlișkisi}

Cinsiyeti konu alan yeni araştırma eğiliminin "cinsiyet farklılıkları" üzerine değil de "cinsiyet benzerlikleri” üzerine odaklanmak olduğu görülmektedir (Else-Quest ve Hyde, 2018). Genel olarak baktığımızda, araştırma bulguları biyolojik cinsiyetin kişilik, bilişsel nitelikler, liderlik ve benzeri birçok alanda ya çok az rolü olduğunu ya da hiç bir belirleyici rolü olmadığını göstermektedir (Hyde, 2005). Zell, Krizan ve Teeter (2015), 106 meta-analizi içeren çalışmalarında, iki cinsiyet arasındaki farklılığın birçok açıdan yok denecek kadar az olduğu sonucuna ulaşmışlardır. Hyde (2005), 1980'li y1llardan itibaren, psikolojik ve bilişsel nitelik ve beceriler, sözel ve sözsüz iletişim, liderlik, benlik saygısı, ahlaki akıl yürütme, motor beceriler gibi alanlarda cinsiyetin etkilerini konu alan çalışmaları içeren toplam 46 meta-analiz çalışmasını incelemiş, kadınlarla erkeklerin birçok açıdan benzer olduğunu ortaya koymuştur. Bu bulgulardan yola çıkarak, kadınlarla erkekler arasında, çocukluktan yetişkinlik dönemine dek psikolojik değişkenler açısından farklılıktan çok benzerlik olduğuna dikkat çekmiş ve "toplumsal cinsiyet benzerlikleri hipotezini (gender similarities hypothesis)" oluşturmuştur (Hyde, 2005). Else-Quest ve Hyde (2018), kadınlarla erkekler arasında, benzerliklerin yanında az sayıda farklılık olduğuna, tüm bu araştırmalarda, toplumsal cinsiyet benzerliği hipotezini destekler biçimde ya hiçbir cinsiyet farklılığı ortaya konmadığına ya da son derece düşük güçte etkiler açı̆̆a çıkarıldığına işaret etmektedir.

Toplumsal cinsiyet benzerlikleri hipotezi doğrultusunda, kadınlarla erkekler arasındaki çok sayıda benzerliğin yanında var olduğu ortaya konan az sayıda cinsiyet farklılığı şu şekilde sıralanabilir; erkeklerin fiziksel saldırganlık düzeyleri kadınlardan daha yüksektir (Archer, 2004), duygusal yakınlık içinde olmadıkları kişilerle cinsel yakınlık kurmaya ilişkin daha olumlu bir tutum içindedirler ve kadınlardan daha çok mastürbasyon yapmaktadırlar (Petersen \& Hyde, 2010). Cinsiyet, uzun y1llar, görünürlüğü çok yüksek olan bir değişken olarak saldırganlığın belirleyicilerinden biri olarak gösterilmiştir. $\mathrm{Bu}$ nedenle, saldırganlığın sayılan temel farklılıklardan biri olarak kendini göstermesi kuşkusuz çok şaşırtıcı değildir. Biyolojik cinsiyet temelinde insanları kadın ve erkek olarak sinıflandırmak son derece kolaydır ve bu siniflandırma da beraberinde birçok temel duygusal ve davranışsal beklentiyi getirmektedir. Cinsiyet rolü beklentileri ve kalıpyargıları özellikle de saldırganlık gibi kolaylıkla gözlenebilir ve dikkat çekici eğilimler söz konusu olduğunda kendisine çarpıcı ve kalıcı bir yer edinmektedir. Evrensel olarak, yıllar boyunca, erkeklerin kadınlardan daha saldırgan olduğu kabul görmüştür (Richardson ve Hammock, 2007). 
Saldırganlıkta cinsiyet farklılıkları y1llardır üzerinde çok sayıda bilimsel araştırma yürütülmüş olan bir konudur. Saldırganlığı ve şiddete eğilimi yordayan bireysel değişkenlere bakıldığında, bu ilişkinin en temel yordayıcısının cinsiyet olduğu görülmektedir (Marcus, 2017). Güncel bulgular, cinsiyet rolü kalıpyargılarını doğrular şekilde, saldırganlıkla ilişkisi en net ve kararlı olan değişkenin cinsiyet olduğunu göstermektedir (Eisner ve Malti, 2015). Altmış sekiz boylamsal araştırmayı kapsayan bir meta-analiz sonucunda, 15-25 yaş aralığına kadar, cinsiyetin saldırganlığın temel yordayıcısı olduğu ve ergenliğin sonlarına doğru da, diğer sosyal ve bireysel değişkenler içinde en etkili risk faktörü olarak belirlendiği görülmüş̧; erkeklerin kadınlardan daha saldırgan olduğu sonucuna varılmıştır (Lipsey ve Derzon,1998).

Saldırganlık ve cinsiyet ilişkisi farklı ölçüm yöntemleri, farklı saldırganlık türleri, yaş ve gelişim dönemleri, saldırgan-kurban arasındaki ilişkinin türü, hedefin cinsiyeti ve saldırganlığın altında yatan güdülenme temelinde ele alınmaktadır. Bu çalışmada da, araştırma bulguları sırasıyla bu temel ölçütler çerçevesinde aktarilacaktır.

Hyde (1984), saldırganlıkta cinsiyet farklılıklarını konu alan 143 araştırmayı kapsayan meta-analiz çalışması sonucunda, bu farklılığın oldukça düşük olduğu bulgusuna ulaşmıştır. Ancak, bu durumun özünde kullanılan araştırma ve ölçüm yöntemiyle yakından ilişkili olduğunu, örneğin, bu farklılığın, doğal gözleme dayalı olan ve ilişkisel araştırmaların sonuçlarına göre deneysel yöntemin kullanıldığı araştırma sonuçlarına kıyasla daha yüksek bulunduğunu belirtmektedir. Ayrıca, cinsiyet farklılığının doğrudan gözlem, projektif test ve akran değerlendirmesi sonuçlarında, kendini değerlendirme, ebeveyn değerlendirmesi ve öğretmen değerlendirmesi sonuçlarına kıyasla daha yüksek olarak belgelendiği görülmektedir.

Birçok farklı kültürde gerçekleştirilmiş 264 araştırma üzerinde yapılan bir başka meta-analiz çalışması da bu farklılığın öfke alt boyutunda gözlenmezken, sözel ve fiziksel saldırganlık açısından gözlendiğini ortaya koymuştur (Archer, 2004). Birçok çalışmada ( örn., Bettencourt ve Miller, 1996; Harris, 1996; Richardson, Vandenberg ve Humphries, 1986) erkeklerin fiziksel saldırganlık düzeylerinin kadınlara kıyasla daha yüksek olduğu ifade edilmekte ve aynı zamanda, erkeklerin daha sık saldırganlık ve şiddet içeren suçlara karışmakta olduğu belirtilmektedir.

Ancak, tüm bu araştırma sonuçları bir yana, "dolaylı saldırganlık" kavramının literatüre girmesiyle birlikte, 1990'lı yıllardan sonra bulguların farklılaşmaya başladığı görülmektedir (örn., Björkqvist ve Niemela, 1992; Crick ve Grotpeter, 1995; Galen ve Underwood, 1997; Lagerspetz, Björkqvist ve Peltonen, 1998). Böy- lece, "kadınların erkeklerden daha az saldırgan olduğu" yönündeki inanış yerini "kadınların başvurdukları saldırganlık türlerinin erkeklerinkinden farklı olduğu” yönündeki görüşe bırakmıştır (Björkqvist, 2018).

Dolaylı saldırganlık, bir bireye sosyal açıdan zarar vermeyi hedefleyen, diğerlerinin ondan hoşlanmamas1na neden olmaktan tutun da, öç almak için bir bireyin rahatsız olacağını bile bile değer verdiği bir arkadaşıyla yakınlık kurmak, sırlarını başkalarıyla paylaşmak, hakkında dedikodu yapmak, alaycı bir beden dili yoluyla ona hasar verecek mesajlar göndermek ve insanlara ondan uzak durmalarını önermeye kadar geniş bir davranış grubunu kapsamaktadır (Vaillancourt, 2013). Bir başka yaygın olarak kullanılan tanıma göre ise dolaylı saldırganlık "hedef kişiye psikolojik ve/veya sosyal açıdan zarar vermek amacıyla, çoğunlukla dolambaçlı yollarla (kötü niyetli dedikodu yaparak, sosyal ağları mağdurun gözden düşüp dişlanmasına neden olacak şekilde manipüle ederek ve onun arkadaş gruplarından dışlanmasını sağlayarak) gerçekleştirilen bir tür sosyal manipülasyon" dur (Björkqvist, 2018, s. 39). Dolaylı saldırganlık yakın ilişkilerden işyerindeki ilişkilere kadar uzanan bir bağlama sahiptir. Bağlama göre değişse de, genel olarak bu davranışın altında yatan temel niyetin, bir başka bireyin sosyal ilişkilerini ve itibarını zedelemek ya da sosyal grubundan dışlanmasına yol açmak olduğu söylenebilir (Archer, 2010).

Literatürde, birbirine benzer olmakla birlikte kendi içinde bir takım farklılıklar içeren, buna rağmen çoğu zaman birbiri yerine kullanılan üç ayrı saldırganlık türünün yer aldığ 1 görülmektedir. Bu durumun yarattığ karmaşasından kurtulmak için kısa bir açıklama yapmakta yarar vardır. Sözü edilen bu üç saldırganlık türünden ilki olan sosyal saldırganlı̆̆ (social aggression), bir başka bireyin benlik saygısına ve/veya sosyal konumuna zarar vermek amacıyla gerçekleştirilen davranış olarak tanımlayabiliriz (Cairns ve ark., 1989). İkincisi ilişkisel saldırganlıktır (relational aggression) ve bu davranış, bir başka bireyin ilişkilerini kasten manipüle ederek bozmayı hedefleyen bir davranış türü olarak tanımlanmaktadır (Crick ve Grotpeter, 1995). Üçüncüsü ise, daha önce ayrıntılı bir şekilde tanımlamış olduğumuz dolaylı saldırganlıktır (indirect aggression). Her üç davranış da sosyal açıdan manipüle edici olan dolambaçlı davranışlardır (örneğin, birisi hakkında gerçek dışı düşmanca söylentiler yaymak). Ancak, sözü edilen bu üç saldırganlık türü yer yer benzerlikler içerdiği için, literatürde bir kavram karmaşasının doğması da kaçınılmaz olmuştur. "Dolaylı saldırganlık" diğer ikisini de kapsayan çok daha net bir kavramsallaştırmaya sahip gibi görünmektedir. Son yıllarda hepsini dolaylı saldırganlık adı altında toplama konusunda bir tür görüş birliği bulunduğu söylenebilir (örn., Björkqvist, 2018; Richardson ve Green, 
2006; Vaillancourt ve Krems, 2018). Bu çalışmada da bu eğilim benimsenecek ve diğer iki tür, dolaylı saldırganlık şemsiyesi altında toplanacaktır.

Finlandiya'da ergenler üzerinde yürüttükleri çalışmalar 1şı̆̆ında, Lagerspetz, Björkqvist ve Peltonen (1998) ve Björkqvist (2018), saldırganlıkta cinsiyet farklılıklarını araştırırken bu davranışı şu üç farklı grupta değerlendirmenin işlevsel olacağı kanısına varmışlardır: $f$ ziksel saldırganlık (physical aggression), doğrudan sözel saldırganlık (direct verbal aggression) ve dolaylı saldırganlık (indirect aggression). Gerçekleştirdikleri araştırmalarda, kadınların bunların içinde dolaylı saldırganlığa erkeklerden daha sık başvurdukları ortaya konmuştur. Österman ve arkadaşları (1998) bu farklılığın kültürel mi yoksa evrensel mi olduğunu sorgulamak amaciyla, Finlandiya, İsrail, İtalya ve Polonya'yı içeren bir araştırma yürütmüşlerdir. Bu kültürlerarası çalışma sonrasında sözel saldırganlığın kadınlarda ve erkeklerde eşit düzeyde var olduğu, ancak erkeklerin kadınlardan daha fazla fiziksel saldırganlığa ve kadınların da erkeklerden daha fazla dolaylı saldırganlığa başvurdukları ortaya konmuştur. Archer 2009 y1lında gerçekleştirmiş olduğu daha güncel araştırmaları da içeren kapsamlı meta-analiz çalışmasında, farklı yaş gruplarındaki erkeklerin daha çok doğrudan saldırganlık (hem fiziksel hem de sözel), kadınlarınsa daha çok dolaylı saldırganlık sergilediklerini belirlemiştir.

Gelişimsel araştırmalara baktığımızda, saldırgan eylemlerin yaşamın ilk yıllarından itibaren görülmeye başlandığ 1 ve saldırganlıkta cinsiyet farklılıklarının farklı yaş gruplarında farklı bir seyri olduğu ortaya çıkmaktadır. Bebeklik döneminde saldırganlık açısından herhangi bir cinsiyet farklılığı gözlenmezken, erken çocukluk döneminde "araçsal saldırganlık", okul öncesi dönemde "fiziksel saldırganlık", ilkokul döneminde "dolaylı saldırganlık" ve ortaokul-lise döneminde "grup ve çete kavgasına karışma", "ağır fiziksel zarar verme”, "cinsel şiddet" ve "cinayet işleme" açısından belirgin cinsiyet farklılıklarının gözlendiği görülmektedir (Krahe, 2011, s. 60).

Card ve Little (2006), çocukluk ve ergenlik dönemlerinde doğrudan ve dolaylı saldırganlığ konu alan 148 çalışmayı kapsayan bir meta-analiz gerçekleştirmişler ve beklendiği gibi, erkeklerin doğrudan saldırganlık, kızların ise (çok az bir farkla) dolaylı saldırganlık eğilimlerinin daha yüksek olduğu sonucuna varmışlardır. Dolaylı saldırganlıkta gözlenen bu farklılık, kullanılan yöntemden bağımsız olarak tüm araştırmalarda değişmez, ortak bir bulgu olarak karşımıza çıkmaktadır (Card ve Little, 2006). Ancak, bu çalışma, meta-analize sokulan araştırmalarda kullanılan yöntemlerin çeşitliliği (kendini-tanımlama, anababa görüşü, öğretmen görüşü, akran görüşü gibi), aralarında dolaylı saldırganlığı tanımlama ve sınırlarını belirleme açısından belirgin farklılıklar olduğu ve böylece, 148 çalışmanın gerçekten de karşılaşt1rılmaya uygun olup olmadığı yönünde eleştirilere maruz kalmaktadır. Yöntem açısından bakıldığında, akran değerlendirmeleri, dolaylı saldırganlık sosyal beğenirliği yüksek olan bir davranış biçimi olmadığ kendine ilişkin değerlendirmelerinden daha güvenilir gibi görünmektedir (Björkvist, 2018). Smit, Rose ve Schwartz-Mette (2009) akran değerlendirmesi yoluyla gerçekleştirilen çalışmalarda da kızların dolaylı saldırganlık düzeylerinin erkeklerinkinden yüksek olduğunu görmüşlerdir.

Gelişim dönemleri arasındaki bu benzerliğin yanında, bu yaş dönemlerinde yetişkinlerle kıyaslandığında dolaylı saldırganlık açısından daha düşük bir cinsiyet farklılığı kaydedildiği görülmektedir. Saldırganlıkta cinsiyet farklılıklarının (özellikle fiziksel saldırganlıkta) ergenlik ve genç yetişkinlik dönemlerinde hızlı bir artış gösterdiği de diğer bir önemli bulgu olarak karşımıza çıkmaktadır (Archer, 2009). Bu durumu, dolaylı saldırganlıkla bilişsel gelişim arasındaki ilişkiyle açıklamak mümkündür. Österman ve arkadaşlarına (1998) göre dolaylı saldırganlık belirli bir düzeyde sosyal zekâyı gerektirmektedir. Sosyal ortamı manipüle etmek isteyen bir çocuğun, bunu yapabilmek için koşulları analiz etme yetisine sahip olması gerekmektedir. Österman ve arkadaşları (1998) sekiz yaşındaki bir çocuğun da dolaylı saldırganlık sergileyebildiğini, ancak on beş yaşına erişmiş kızların daha küçük yaştakilere kıyasla çok daha fazla dolaylı saldırganlığa dönük strateji geliştirebildiğini belirlemişlerdir.

Owens, Shute ve Slee (2000) k1zların dedikodu yapma, dışlama, aşağılama, kılık kıyafet, dış görünüş ve kişiliğe ilişkin olumsuz eleştirilerde bulunma gibi dolay11 saldırganlık içeren davranışlara yönelmelerinin altında; misilleme yapma, grup içinde kendine bir yer edinme ve bu konumu koruma, heyecan arama, can sikıntısını giderme, kurban konumuna düşmemek için kendini koruma gibi amaçlar içeren bir güdülenmenin yattığını belirtmektedirler. Aynı zamanda, dış görünüş, başarı, arkadaşlar ve erkeklerin ilgisini çekme gibi konulardaki kıskançlığın da bu eğilimin tetikleyicisi olduğu görülmektedir (Owens, Shute ve Slee, 2000). Kizlar bu tür saldırgan eğilimlerden erkeklere nazaran (daha hassas olduklarını ifade ederek) daha büyük yaralar aldıklarını belirtmektedirler (Galen ve Underwood, 1997).

Richardson ve Green (1999), katılımcıların hemcinslerine ve karşı cinse yönelik doğrudan ve dolaylı saldırganlık eğilimlerini ölçtükleri çalışmalarında, erkeklerin erkeklere doğrudan saldırganlık eğilimlerinin çok daha yüksek olduğu sonucuna varmışlardır. Aynı araştırmada, kadınların da kadınlara daha fazla dolaylı saldırganlık sergiledikleri, ancak kadınların genel do- 
laylı saldırganlık puanlarının erkeklerinkinden yüksek olmadığ 1 ortaya konmuştur. Hem kadınların hem de erkeklerin hemcinslerine sergiledikleri saldırganlığın kendi içinde farklı dinamikleri olduğu da görülmektedir. Örneğin, kadınlar çekici kadınlara yüksek düzeyde dolaylı saldırganlık uygularken, erkeklerde benzeri bir durum gözlenmemektedir (Vaillancourt, 2013).

Richardson ve Green (1999) bulgularını tartışırken, bu durumun ilişkinin türüyle de ilintili olduğunu vurgulamış; insanların cinsiyete göre farklılık göstermeksizin, flört ettikleri ya da evli oldukları bireye yönelik davranışlarıyla kız kardeş, anne, baba ya da sıradan bir arkadaşlarına yönelik davranışlarının da farklılaşacağını ifade etmişlerdir (s. 433). Saldırganlığın türüyle aktörle (saldıran) kurban arasındaki ilişkinin türü arasındaki bağlantının da belirleyici bir değişken olduğu görülmektedir. Romantik ilişkilerde doğrudan saldırganlığın, arkadaşlık ilişkilerindeyse dolaylı saldırganlığın daha çok sergilendiği, doğrudan saldırganlıkta cinsiyetten çok ilişki türünün yordayıcı olduğu görülmektedir (doğrudan saldırganlık, karşı cinsten ve hemcins arkadaşlardan çok romantik partnere yöneltilmektedir) (Richardson ve Green, 2006). Ancak, dolaylı saldırganlıkta, hem cinsiyetin hem de ilişki türünün rolünün olduğu, bireylerin hemcinslerine kıyasla karşı cinse daha az dolaylı saldırganlık gösterdikleri ve romantik partnerlerine normal arkadaşlarına (hemcins ve karşı cins) kıyasla daha az dolaylı saldırganlık sergiledikleri ortaya konmuştur.

Evli bireylerde ise, sözel ve fiziksel saldırganlık açısından düşük bir cinsiyet farklılığ 1 ortaya konmakta, hatta kimi zaman kadınların erkeklerden daha saldırgan olduğu bulgusu ile de karşılaşılmaktadır (Archer, 2000). Fiziksel saldırganlık evlilik içinde de erkeklerin tipik olarak daha sık başvurdukları bir doğrudan saldırganlık türü iken, kadınların evlilik içinde "psikolojik saldırganlık" sergilemeye daha eğilimli oldukları görülmektedir. Evlilikte psikolojik saldırganlığ 1 kısaca "eşin benlik değerini ve benlik kavramını hedef alan saldırılar" olarak tanımlayabiliriz (örn., alay etme, sözel olarak küçümseme ve aşağılama, eşi ailesinden ve arkadaşlarından uzaklaştırmaya ve yönetmeye/denetlemeye çalışma) (Hammock ve O'Hearn, 2002, s . 423). Psikolojik saldırganlık, hem yüz yüze iletişim kurma olanağı sunduğu, hem de partneri/eşi yakından tanımayı gerekli kıldığı için yakın ilişkilerde daha sık sergilenen bir saldırganlık türüdür ve fiziksel güç ya da cinsiyete dayalı bir farklılık olarak değerlendirilebilecek bir beceri gerektirmediği için, hem kadınlar hem de erkekler tarafindan sergilenmesi olasıdır. Ancak buna rağmen, kadınların erkeklerden daha çok psikolojik saldırganlık sergilediğini gösteren çok sayıda araştırma bulunmaktadır (Hamby ve Sugarman, 1999; Jezl, Molidor veWright, 1996; Kasian ve Painter, 1992; Marshall, 1994; Molidor, 1995; Stets, 1991).
Her ne kadar bu farklılık düşük olsa da, kadınlarla erkekleri bu yönde farklılaşmaya iten güdülenmenin ne olduğunu sorgulamakta fayda vardır. Hammock ve O’Hearn (2002), bu farklılığın bazı bireysel ve ilişkisel değişkenlerle ilişkisi üzerine araştırmalar yürütmüşlerdir. Uzun süreli ilişkilerde, fazla alkol tüketen, kendini tehdit altında hisseden ve çatışmaları etkin yöntemlerle çözme becerilerine sahip olmayan erkeklerle, eşiyle çatışmaktan kaçınan ya da çatışmalarda pes etmeye eğilimli olan, kendini tehdit altında gören kadınların psikolojik saldırganlığı daha sık sergiledikleri sonucuna varmışlardır. Her iki cinsiyetteki bireylerde de psikolojik saldırganlık, etkili olmayan çatışma çözme stratejilerini yordamaktadır. Burada kadınlarla erkekler arasındaki temel farklılık, kullanılan "etkili olmayan çatışma çözüm stratejisinin türü"dür. Psikolojik saldırganlık sergileyen erkeklerin, etkin çatışma çözümü stratejilerini kullanmaya isteksiz olan ya da bunu başaramayan bireyler oldukları, aynı seçimi yapan kadınların da ya çatışmadan kaçınan ya da çatışma anında eşlerinin isteklerine boyun eğen kadınlar olduğu ortaya konmuştur. Hammock ve O’Hearn (2002), erkeklerin eşle dalga geçmek, diş görünüşüyle ilgili kötü eleştirilerde bulunmak ya da ona ait bir şeye zarar vermek gibi saldırılarda bulunduklarını; kadınlarınsa küfretmek ya da sözle aşağılamak, odayı hızla terketmek gibi daha dișavurumsal saldırılarda bulunduklarını belirlemişlerdir. Hammock ve O'Hearn'e göre (2002) erkeklerin kullandıkları psikolojik saldırı türleri çok daha çeşitlidir ve bu durum, büyük oranda kadınlarla erkeklerin psikolojik saldırganlığa yükledikleri anlamın ve davranışın altında yatan güdülenmenin farklılaşmasından kaynaklanmaktadır. Erkekler bu eylemleri eşlerine zarar vermek ve onu denetleyip manipüle etmek için, kadınlarsa hoşnutsuzluklarını ve duygusal çalkantılarını dışa vurmak için kullanıyor gibi görünmektedirler.

Buradan hareketle, cinsiyetle saldirganlık arasındaki ilişkiyi sorgularken yanıtın "hedefle kaynak arasındaki (aktörle kurban) ilişkinin türüne", "saldırganlığın türüne" ve aynı zamanda "hedefin cinsiyetine" göre değişeceği gerçeğini göz önünde bulundurmak gerekmektedir.

\section{Kuramsal Yaklaşımlar}

Daha önce de değinildiği gibi, saldırganlık ve cinsiyet arasındaki ilişkiyi açıklama çabasında olan belli başlı kuramlar bulunmaktadır. Bu kuramlar, bir anlamda, yukarıda yer verilen bulguların kaynağını sorgulama misyonunu üstlenen bilimsel yaklaşımlardır. Bu nedenle, bu kuramsal yaklaşımları ele almak, belirli saldırganlık türlerindeki cinsiyet farklılıklarını daha iyi kavramak, bu farklılıklara zemin hazırlayan güdülenmeleri irdelemek, kadınları ve erkekleri farklı koşullarda ve farklı boyutlar- 
da farklı saldırganlık eğilimlerine iten temel etmenlerin köküne inmek adına önemlidir. Literatüre baktığımızda, saldırganlıkla cinsiyet arasındaki ilişkiyi açıklama çabalarının çoğunlukla genetik ve evrimsel, biyolojik, sosyal öğrenme ve sosyal rol temelli olduğu görülmektedir. İzleyen alt bölümde de, bu yaklaşımlar, alt başlıklar halinde kısaca sırasıyla ele alınacaktır.

\section{Genetik ve Evrimsel Kökenli Yaklaşımlar}

Hayvanlar iki nedenle kavga ederler; tehlikeyi uzak tutmak ve kaynaklar için rekabet etmek. Saldırganlık hayatta kalmak için rekabet etmenin yollarından biridir ve kar/zarar dengesi çerçevesinde bir eylem olarak değerlendirilebilir (Archer ve Cote, 2005). Bu dengenin tipik olarak cinsel ayıklanma (sexual selection) ile kendini gösterdiği söylenebilir. Birkaç istisna dışında, erkeklerin kadınlara kıyasla, birbirleriyle dövüşerek elde edecek daha çok şeyleri ve dövüşmedikleri takdirde kaybedecek daha çok şeyleri vardır. Darwin (1871), saldırganlığı da, tüm diğer davranışsal eğilimler gibi, soyunu sürdürme ve hayatta kalma ile ilişkilendirir. Evrimsel Yaklaşıma göre saldırganlık, insanın eş bulma, üreme ve hayatta kalmayla ilgili kaynakları için savaşma gerekliliğinin bir uzantısıdır. Bu yaklaşım erkeklerin saldırganlık eğilimini, doğurganlık düzeyi yüksek kadınlarla eşleşme olanaklarını artırmak için girdikleri yarışın doğurduğu uyumsal bir gereklilik olarak değerlendirmektedir.

Trivers'a göre (1972), germ hücrelerindeki bir uzmanlaşma kadınlarla erkeklerin anababasal yatırım (parental investment) açısından farklılaşmasına yol açmakta, kadınlar yumurta hücresi üretimine çok daha fazla zaman ve enerji yatırımı yapmakta, bu nedenle güçlü ve uyumlu bir eş seçememenin bedeli onlar için daha ağır olmaktadır. Ancak erkekler bu anlamda daha az yatırım yaptıkları için daha az bedel ödemektedirler. Bu farklılık kadınları eş seçimi konusunda daha seçici kılmakta ve erkekleri de kadınlar tarafindan tercih edilmek ve bu tercihi etkileyecek kaynaklara erişmek için rekabete sürüklemektedir. Trivers'ın Anababasal Yatırım Modeli (1972), erkeğin istisnai olarak daha fazla yatırım yaptığg türlerde kadınların daha saldırgan olduğunun gözlenmesi ve her iki cinsin de eşit yatırım yaptığı türlerde saldırganlıkta cinsiyet farklılığının gözlenmemesi bulgularıyla desteklenmektedir.

Özellikle genç erkekler saldırganlık yoluyla güç ve statü gösterisi yapmakta ve diğer erkeklerle rekabete girmektedir (Archer, Holloway ve McLoughlin,1995). Benzer şekilde, statüleri tehlikeye giren erkekler de bu durumu ortadan kaldırıp sosyal konumlarını onarmak için saldırganlığa başvurmaktadırlar. Bu durumda, toplumsal statüsü düşük olan erkeklerin daha güçlü olanlardan daha saldırgan davranmaları beklenmelidir. Archer, Holloway ve McLoughlin (1995), bunu sinamak için gerçekleştirdikleri araştırma sonucunda, işsiz erkeklerin, sosyal konumu göreli olarak daha yüksek olan erkeklere göre çok daha kolay kavgaya giriştikleri bulgusuna ulaşmışlardır.

Doğrudan saldırganlık türleri, hem kadınlarda hem de erkeklerde $\% 50$ oranında genetik ve çevresel etmenlerle ilişkilendirilmektedir (Björkvist, 2018). Dolaylı saldırganlığın genetik kökeninin olup olmadığı ya da tümüyle öğrenmeye dayalı bir alt yapıya dayanıp dayanmadığı üzerine birçok tartışma yürütülmektedir. Tackett, Waldeman ve Lahey (2009) dolaylı saldırganlığın da hem genetik hem evrimsel alt yapılarının önemle vurgulanması gerektiğini savunmaktadırlar. Vaillancourt, Miller ve Sharma'ya (2010) göre bunun en belirgin kanıtı kadınların erkekler için hemcinsleriyle girdikleri rekabettir. Diğer yandan, erkekler çocukları için kısmen daha az yatırım yapıp emek harcadıkları için diğer erkeklerle ve tehditlerle baş etmek için doğrudan, fiziksel yolla savaşmak onlara düşmektedir. Ayrıca, kadının çocuğuna vereceği bakım babanınkinden daha fazla yaşamsal ve uyumsal önem taşıdığı ve kadının bu anlamda fiziksel olarak da kendini daha çok sakınması gerektiği için, kadın sadece az hasar verici saldırganlık ya da dolaylı saldırganlık yoluyla çatışmalarını çözmektedir (Archer ve Coyne, 2005). Bunun yanında, dolaylı saldırganlık fiziksel saldırganlığa kıyasla çok daha başarı11 bir grup-içi stratejidir. Hess ve Hagen'e (2006) göre, kadınlar olumsuz dedikodudan erkeklere göre çok daha fazla zarar görmekte, tam da bu nedenle saldırganlıklarını diğer kadınları yaralamak için bu stratejiyle hayata geçirmektedirler.

Evrimsel psikologlar, erkeklerin fiziksel açıdan daha güçlü, saldırgan ve cesur, kadınlarınsa doğurgan ve bakım verici olduğu toplumların doğal ayıklanma sürecinden galip çıktığını savunmaktadırlar (Fine, 2011). Evrimsel bakış açısına göre, tarih öncesi dönemlerde temelde eş bulmak için rekabet eden, kavgaya ve hatta adam öldürmeye meyilli erkeklerin, diğerlerine kıyasla bu savaşı kazanıp eş bularak soylarını sürdürme olasılıkları daha yüksekti. Bu nedenle, yüksek fiziksel saldırganlık genetik olarak da kuşaktan kuşağa geçecek bir nitelik olarak varlığını sürdürmüştür. Bu yaklaşıma göre kadınlarla erkeklerin biyolojik yapıları zamanla farklılaşarak evrimleşmiş, bu durum erkeklerin doğaları gereği daha atılgan, cesur ve şiddete eğilimli, kadınlarınsa daha kırılgan, zarif, anaç ve besleyici olmalarıyla kendini göstermiştir. Bu açıdan bakıldığında, geleneksel cinsiyet rollerinin özünde evrimsel bir temel olduğu ve bu nedenle de, biyolojik kökeni olan bir durumu değiştirme çabasının çok da yerinde olmadığı vurgulanmaktadır. Bu evrimsel açıklamalara birçok farklı boyutta eleştiri getirilmektedir (Begley, 2009; Fine, 2011). İlk olarak, tarih öncesi dönemlerde kadınlarla erkeklerin davranış ve tutumları 
arasında evrimsel yaklaşımda sözü edilenden çok daha fazla farklılık olduğu öne sürülmektedir. İkincisi, biyolojik farkl1lıklar tarih öncesi dönemde toplumsal cinsiyet rollerini belirleme gücünü sahipse de, günümüzde bu durum geçerli değildir; örneğin, fiziksel güç, eskisi gibi hayatta kalmak için gerekli değildir. Üçüncüsü, evrimsel yaklaşım, var olan cinsiyet eşitsizliklerini bu şekilde, bir anlamda haklı gösterip adeta kadınlarla erkekleri geleneksel cinsiyet rollerinin içine hapsetmektedir. Son yıllarda yapılan antropolojik çalışmaların bulguları da, erkeklerin şiddete başvurma eğilimlerinin biyolojik olarak aktarıldığı yönündeki görüşü desteklememektedir. $\mathrm{Bu}$ çalışmalar, şiddet eğilimi yüksek olan erkeklerin, öne sürüldüğü gibi kadınlar tarafindan daha çok tercih edilmediklerini, çünkü bu erkeklerin eşlerinin ve çocuklar1nın soylarını sürdürmek bir yana, düşmanları tarafından öldürülüp erkenden hayatlarını kaybettiklerini ortaya koymaktadir (Begley, 2009).

Saldırganlıkta cinsiyet farklılıkların evrimsel kökeninin yanında, birçok davranışta olduğu gibi saldırganlıkta da biyolojinin ve hormonların etkisi olduğu kuşku götürmez. Aşağıda kısaca konuyu bu açıdan değerlendiren yaklaşım ve araştırmalara değinilecektir.

\section{Hormonal Açıklamalar}

Saldırganlıkta cinsiyet farklılıklarını açıklamak için yaygın olarak benimsenen yaklaşımlardan bir diğeri de hormonlara dayanmaktadır (Mazur, 2009). Hayvanlarda erkek saldırganlığı ve testosteron ilişkisinin varlığını kanıtlayan birçok örnek bulunmaktadır. Bu durum tüm memeliler için geçerli gibi görünmekle birlikte, istisnai türler de vardır (lemurlarda ve sırtlanlarda durum tam tersidir) (Björkqvist, 2018). Evrimin alt basamaklarındaki canlılarda bu ilişki çok belirginken, üst basamaklara çıkıldıkça bu ilişkinin zayıfladığı görülmektedir (Björkqvist, 1994). Archer (1991) üç ayrı meta-analiz çalışması gerçekleştirmiş ve insanda saldırganlıkla testosteron arasında zayıf bir pozitif ilişki olduğu sonucuna varmıştır. Book, Starzyk ve Quinsey (2001), kırk beş araştırmayı içeren meta-analizlerinde, benzer şekilde bu ilişkinin zayıf ve pozitif olduğunu görmüşlerdir.

Erkeklerde testosteron ergenlik döneminde hizla artmakta, genç yetişkinlikte bu artan düzey korunmakta, ancak orta yaşa doğru azalmaya başlamaktadır (Björkqvist, 2018). Bu örüntü fiziksel saldırganlıkla ilişkili görünmektedir. Daly ve Wilson (1994) bu durumu 'genç erkek sendromu (young male syndrome)'olarak adlandırmakta ve 12-25 yaş aralığındaki erkeklerin fiziksel saldırganlığın temel failleri (aynı zamanda da kurbanlar1) olduğunu belirtmektedirler. Testosteron düzeyini, kazanmak ve kaybetmek (bir yarışı, dövüşü vb.) etkilemekte, kazandığınızda artmakta, kaybedince düșüş göstermektedir. Bu durum güreş ve tenis gibi sporlarda
(Elias, 1981) ve hatta satrançta bile belirgin bir şekilde gözlenmektedir (Mazur, Booth ve Dabbs, 1992). Bu düzey, yarışmanın hemen öncesinde, adeta gelecek bir çatışmanın habercisi gibi artış göstermektedir (Björkvist, 2018). Evrimsel olarak açıklandığında, testosteron erkekler arasındaki rekabetle ilişkili görülmekte ve kadınların da bu rekabette kazananı çekici bulduğu görülmektedir. Testosteron-saldırganlık ilişkisinin eş seçimi konusundaki uyumsal gücü Booth ve Dabbs Jr. (1993) tarafından araştırılmış ve evli erkeklerde bu hormonun düzeyinin zamanla düştüğü ve ardından bir boşanma olana dek de sabit kaldığı saptanmıştır.

Bunun yanında bu görüşün desteklenmesi için aynı bireyin testosteron düzeyindeki farklılıkların davranışına nasıl yansıdı̆̆ı sorusunun da yanıtını verebilmek gerekmektedir. Halpern, Udry, Campbell ve Suchindran (1993) erinlik (puberty) döneminde hızla artan testosteronun saldırganlık düzeyinde de hızlı bir artışı beraberinde getirip getirmediğine boylamsal bir araştırma yürüterek bakmışlar, ancak bu yönde bir bulguya ulaşamamışlardır. Diğer yandan, birçok çalışma iki değişken arasında doğrusal bir ilişki olduğunu gösteriyor olsa da, bu ilişkiyi testoste-

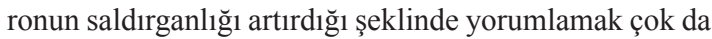
doğru görünmemektedir. Zira, saldırganlık ve şiddet de testosteron artışına neden oluyor olabilir (Miczek, Mirsky, Carey, DeBold ve Raine, 1994).

Öte yandan, doğum öncesi hormonal çevrenin (prenatal hormonal environment) davranışta cinsiyet farkl1lıklarının en temel belirleyicisi olduğunu düşünenler de bulunmaktadır (örn., Björkvist, 2018; Fussell, Rowe ve Park, 2011). 2D:4D parmak oranının (işaret parmağıyla yüzük parmağının uzunlukları arasındaki oran) anne karnında maruz kalınan hormonlarla ilişkili olduğu belirtilmektedir. Daha çok sağ el için vurgulanan bu oran uteroda oluşmaktadır ve prenatal testosteron ile olumsuz, prenatal estradiolle olumlu bir ilişki içindedir. Sağ elde düşük 2D:4D erkeksi davranışsal eğilimle, yüksek 2D:4D ise kadınsı davranışsal eğilimle ilişkili görülmektedir. Araştırmalar, birçok kişilik özelliğiyle ilişkili olduğu sonucuna varılan bu oranın, saldırganlıkla da yakından ilişkili olduğunu göstermekte, erkeklerde fiziksel saldırganlık eğilimiyle düşük 2D:4D arasında yüksek bir olumlu ilişki olduğu öne sürülmektedir (Bailey ve Hurd, 2005).

Erkeklerde saldırganlıkla ilişkili olduğu düşünülen bir diğer hormon da kortizoldür. Kortizol, strese tepki vermeyle yakından ilişkili olan bir hormon olarak değerlendirilmektedir. Benzer şekilde, güven duyma ve yakınlıkla ilişkili olduğu düşünülen oktitosinin de saldırganlıkla ilişkili olduğu, bu hormonun düşük olması durumunda saldırgan eğilimlerde artış gözlendiği belirtilmektedir. Ancak, her iki hormonla saldırganlık arasındaki ilişkiyi ele alan çalışmaların elde ettiği bulgular oldukça çelişkilidir (LaPraririe, Schechter, Robinson ve Brenn, 2011). 
Van Goozen (2005) biyolojik ve hormonal etmenlerin insan davranışı üzerindeki etkilerini "deterministik" olarak değerlendirmemek gerektiğini belirtmektedir. Çevre ve kültür, ödüllendirme, cezalandırma, görmezden gelme gibi yollarla biyolojik kökeni olan davranışı dönüştürebilir, sergilenme sıklığını azaltıp çoğaltabilir (Reinisch ve Sanders, 1992). Bu etmenlerin saldırganl1ğın oluşumu üzerindeki etkisini sorgularken, davranışın bireysel, gelişimsel ve toplumsal etmenlerin karşılıklı etkileşimi sonucunda belirlendiği gerçeğini de yadsımamak gerekir. Bunlardan hangisinin daha güçlü bir etkisinin olduğunu, bireyin içinde bulunduğu gelişim evresi belirlemektedir. Örneğin erken çocukluk döneminde aşırı disiplinli bir anababanın bu tutumu antisosyal davranışın oluşumuna yol açabilirken, ilgisiz anababa tutumu aynı etkiye geç çocukluk ve ergenlik dönemlerinde yol açabilmektedir (Krahe, 2011). Bu bağlamda, sosyal öğrenme temelli yaklaşımların saldırganlıkta cinsiyet farklılıklarını açıklamada en sık başvurulan bakış açılarından biri olması da son derece beklenen bir durumdur. Aşağıda kısaca bu yaklaşımların konuya bakışı üzerinde durulacaktır.

\section{Sosyal Öğrenme Kuramları}

Saldırganlıkta cinsiyet farklılıklarını ele alan yaklaşımların en önde gelenlerinden birisi de kuşkusuz Sosyal Öğrenme Kuramlarıdır (örn., Bandura, 1973). Bu bakış açısına göre saldırganlık da tüm diğer davranışlar gibi, gözlem yapma, model alma, taklit etme, ödüllendirme, pekiştirme gibi süreçler yoluyla, öncelikle anne babadan, ardından diğer otorite figürlerinden, akranlardan ve medyadan öğrenilmektedir (Bandura, 1978).

Sosyal Öğrenme Kuramı, insanlarda saldırganlığı başlatan, tetikleyen ve sürdüren etmenler üzerinde durmaktadır (Snethen ve Puymbroeck, 2008). Bu yaklaşımda saldırganlık doğuştan var olan bir özellik olarak değil, sonradan öğrenilen, kazanılan bir eğilim olarak değerlendirilmektedir (Bandura,1978). Bandura'ya göre $(1973,1978)$ insanlarda saldırganlığa yönelik bir kapasite bulunmakla birlikte, bunu sergilemek için bireyin öncelikle davranışı öğrenmesi, saldırganlığı tetikleyecek koşulların olması ve saldırgan davranışı pekiştiren içsel ve dışsal koşulların varlığı gereklidir. Model alma saldırganlığın öğrenilmesinde çok temel bir rol üstlenmektedir. Gözlemleme, bireye yalnızca model alınan davranışı öğrenme olanağı değil, aynı zamanda bu davranışın daha yenilikçi versiyonlarını üretme ve sergileme olanağ erkeklerin fiziksel saldırganlık düzeylerinin, kadınlarınsa dolaylı saldırganlık düzeylerinin karşı cinse göre daha yüksek oluşunu genetikle değil, aynı cinsteki anababayı model alma ve onunla özdeşleşme ile açıklayabiliriz.

Bandura (1973) bireyin davranışlarının en yakınındaki bireylerinkilerle sınırlı olduğunu belirtmektedir ve bu durum hem yardım etme gibi olumlu toplumsal (prosocial) hem de saldırganlık gibi antisosyal davranışlar için geçerlidir. Yaşamın ilk yıllarında bu modeller aile ile sınırlıyken, çocuk büyüdükçe çeşitlenip farklılaşmaktadır. Bandura (1978) ailesine kıyasla saldırganlık eğilimi daha yüksek olan çocukların ve genç yetişkinlerin içinde bulundukları bu durumu saldırganlık eğilimi yüksek arkadaşlar seçmelerine bağlamaktadır. Werner ve Crick (2004) de bunu destekler şekilde, saldırgan bireylerin saldırgan arkadaşları olduğu bulgusunu ortaya koymuşlardır.

Bandura (1973) televizyonda şiddetin temsilinin bu davranışın öğrenilmesinde büyük rolü olduğunu savunmakta ve bu durumun 4 temel etkiye yol açtığını belirtmektedir;

(1) Saldırgan davranışı öğretmektedir,

(2) Bireyin saldırganlığa ilişkin geliştirmiş olduğu doğal ket vurma güçlerini gevşetmektedir,

(3) Şiddete ilişkin duyarsızlaşmaya yol açmakta ve böylece bireyin bu yönde davranma eğilimini de artırmaktadir,

(4) Bireyin şiddete ilişkin gerçeklik algısını yapılandirmaktadır.

Bandura'nın sözünü ettiği birinci maddeye, televizyon (günümüzde aynı zamanda video oyunları, sinema, sosyal medya) saldırganlığı "bu davranışta gözlenen cinsiyet farklılıklarını ve ilgili kalıpyargıları da vurgulayıp altını çizerek öğretir” önermesini eklemek yanlış olmayacaktır.

Gözleme ve anne-babaların beyanlarına dayanan birçok çalışma (örn., Hay, Castle ve Davies, 2000) çok küçük yaşlarda bile erkek çocukların itme, vurma, elinden isteği dışında bir şey alma davranışlarını açık ara kızlardan daha sık sergilediklerini göstermektedir. Saldırganlıkta cinsiyet farkl1lıklarının 17 aylık bebeklerde bile gözlendiği görülmektedir (Baillargeon ve ark., 2007). Evrimsel açıdan bakıldığında, henüz eş bulma ya da üreme kaynaklarını koruma gibi bir kaygı ortada yokken, çok küçük yaşlarda dahi fiziksel saldırganlıkta cinsiyet farklılıklarının belirlenmiş olması ilginçtir. $\mathrm{Bu}$ yaşlarda oyuncağını ya da bölgesini koruma amaçlı sergilenen saldırganlık, daha sonra statü koruma amaçlı bir yönelime dönüşmektedir. Çocuk çok küçükken başlayan cinsiyet ayrımcılığı (çocuk doğmadan önce, örneğin eşyalarını seçerken), yaş ilerledikçe kızların ve erkeklerin ilişkilerine, arkadaş seçimlerine ve grup içi etkileşimlerine sızmaya başlamaktadır. Erkekler sosyal konumu ve başat rolü daha çok önemsemeye başlamakta, liderlik onlar için daha büyük önem kazanmakta, büyük gruplar halinde oyun oynama pratiği başlamaktadır. Kızlarsa duygusal yatırımı yüksek olan daha yakın ilişkiler kurup az sayıda arkadaşla zaman geçirir hale gelmektedir. Bu ayrışım ilerleyen yıllarda birçok sosyal davranışta göz- 
lemlenecek olan cinsiyet farklılıklarının da tohumunu atmaktadır. Kızlar, fiziksel gücün öneminin vurgulanmasıyla saldırganlığını bu yönde sergilemeyi öğrenen erkek çocuğun aksine, küçük yaşta ileride sıkça başvuracaklar1 dolaylı saldırganlık stratejilerini öğrenme ve deneme eğilimine girmeye başlamaktadırlar (Cote, 2007).

Sosyal öğrenme temelli kuramları kendi içinde ayıran temel nokta, neyin öğrenildiği (davranış, tutum, algısal yanlılıklar, tepkisel yanlılıklar) ve nasıl öğrenildiği (direkt kişisel deneyim ya da taklit etme yoluyla ) üzerine getirdikleri açıklamalardır. $\mathrm{Bu}$ yaklaşımların içinde akılcı önermeleriyle dikkat çeken "Sosyal Senaryo (social script)" modeline göre, çocuklar saldırgan davranışlarına rehberlik eden saldırganlık "şema”larını ya da "senaryo"larını öğrenirler (Hess ve Hagen, 2006, s. 232) . Modele göre, senaryolarda önerilen saldırgan davranışlar benlik düzenleyici inançlar tarafından bir tür filtreden geçirilir, bu inançlardan biri de normatif inançlardır. Saldırganlığı onaylayan, uygun gören normatif inançlarla saldırganlık eğilimi yüksek bir ilişki içindedir. $\mathrm{Bu}$ bakış açısından hareketle, saldırganlıktaki cinsiyet farklılıklarını, saldırganlığın onaylanmasındaki cinsiyet farklılıkları olarak ele almak belki de daha yerinde olacaktır (Huesmann ve Guerra, 1997, s. 409).

Öte yandan, bu yaklaşımların açıklamaları doğrultusunda saldırganlığın yaşla birlikte birikimli bir şekilde artması beklenirken, son yıllarda yapılan boylamsal araştırmaların tam aksini gösteriyor olması temel bir eleştiri olarak karşımıza çıkmaktadır (Archer ve Cote, 2005). Boylamsal çalışmalar belirli bir yaştan sonra saldırgan davranışların ve şiddet eğiliminin azaldığını göstermektedir (Broidy ve ark., 2003). Ancak unutulmamalıdır ki, öğrenme süreçleri saldırgan davranışları olduğu gibi olumlu toplumsal davranışları da (örneğin model alma, ödüllendirme) bize kazandırmakta, ödül yoluyla kazandırdığı davranışları ceza yoluyla söndürmekte ve biçimlendirme, olumsuz pekiştirme gibi yöntemlerle de farklılaştırmaktadır.

Sosyal Öğrenme Kuramlarının yanında, saldırganlıkta cinsiyet farklılıklarını toplumdaki rol dağılımı ve güç temelinde değerlendiren Sosyal Rol Kuramının da yaygın olarak kabul gören yaklaşımlardan biri olduğu bilinmektedir. Aşağıda bu farklılık kısaca bu yaklaşım çerçevesinde irdelenecektir.

\section{Sosyal Rol Kuramı}

Sosyal Rol Kuramına göre, tüm toplumsal davranışlarda olduğu gibi saldırganlıkta gözlenen cinsiyet farkl1lıkları da geçmişten bugüne varlığını sürdüren kadın-erkek rollerine (kadın evde, erkek ev dışında çalışır) dayanmaktadır (Eagly, 1987). Bu rol dağ1lımı, toplumsal cinsiyet rollerinin katılaşmasını ve bunlara uygun beklentilerin yapılanmasinı beraberinde getirmektedir
(Eagly, Wood ve Diekman, 2000). Tüm kültürlerde kadınlardan kadınsı (dışavurumsal), erkeklerden de erkeksi (araçsal) niteliklere sahip olmaları beklenmektedir (Archer, 2004). Cinsiyet rolü kalıpyargıları kadınların daha duygusal ve duygularını dişa vuran, erkeklerinse duygularını dışa vurmayan bireyler oldukları yönündedir (Eagly, 1983; Eagly ve Crowley, 1986; Wood ve Eagly, 2002). Frost ve Averill'e göre (1982), bu durumun istisnai olduğu tek bir koşul vardır ki o da öfkelenme ve öfkenin dişavurumudur. Bu noktada "erkekler ağlamaz" klişesi yerini "erkek adam öfkelenir"e bırakmaktadır. Sertlik, öfke ve saldırganlık geleneksel olarak birçok toplumda erkeksi cinsiyet rolüne atfedilen niteliklerdir ve psikoloji ve antropoloji kökenli araştırmalar da bunun tarih boyunca varlık göstermiş evrensel bir olgu olduğunu kanitlamaktadır (Weaver, Vandello, Bosson ve Burnaford, 2010).

Eagly ve arkadaşları (örn., Eagly ve Crowley, 1986; Wood ve Eagly, 2002) cinsiyetle ilgili toplumsal rollerin saldırgan davranışa rehberlik ettiğini öne sürmektedirler. Toplumsal cinsiyet rolleri, en yüksek hızda nüfus eden ve derin etkilerle hayata geçen rollerdir. $\mathrm{Bu}$ nedenle, iki cinsiyet arasında gözlemlenen saldırganlık eğilimi farklılığı, saldırganlıkla toplumsallaşma ilişkisinin bir doğurgusu olarak değerlendirilebilir (Richardson ve Hammock, 2007, s. 418). Erkeğin toplumsal cinsiyeti, diğer bir deyişle erkeksilik, güç, başatlık ve saldırganlık üzerine kuruludur. Kadınsılık ise, aksine, bakım verme ve koruma gibi, saldırganlıkla yan yana konamayacak özelliklerle ilişkilendirilmektedir. Erkek çocuklar için "kabalık-sertlik" bir sosyal statü göstergesi konumuna gelmekte (Archer, 1992) ve erkek çocuklar “erkek adam kavgadan kaçmaz” öğretisinin etkisi altında kalmaktadır. Kisaca, erkeklerin fiziksel şiddete başvurma konusunda toplum tarafindan daha çok yüreklendirildiklerine ve daha az kısıtlandıklarına inanılmaktadır. Ancak bunu ölçen çok az araştırma vardır ve onların da bulguları çelişkilidir (Archer ve Lloyd, 2002; Maccoby ve Jacklin, 1980). Saldırganlıkta cinsiyet farklılıklarını ele alan sosyal psikolojik çalışmaları inceleyen Eagly ve Steffen (1986), araştırmacının saldırganlığı nasıl tanımlayıp değerlendirdiğinin sonuçları etkilediğini öne sürmekte ve toplumsal rollerin (özellikle de toplumsal cinsiyet rollerinin) rehberliğinde öğrenilen "saldırganlığın sonuçlarına" yönelik algılamanın bu cinsiyet farklılığının temel belirleyicisi olduğunu öne sürmektedirler.

Kısaca, birçok araştırmacı saldırganlığın erkeksi cinsiyet rolü yöneliminin bir uzantısı olarak toplumsallaşma süreci içinde öğrenildiği görüşünü savunmaktadır. Eagly'e göre (1987) cinsiyet rolü toplumsallaşması süreci içinde erkeklerin saldırgan eğilimleri desteklenirken kadınlarınki kısıtlanmaktadır. Kadınlar, bunu doğrular şekilde, saldırgan davranış sergiledikleri zaman güçlü 
bir suçluluk ve kaygı yaşadıklarını belirtmektedirler. Ayrıca, saldırganlık eğilimleri kısıtlanmayan kadınların da erkekler kadar saldırgan oldukları ortaya konmuştur (Krahe, 2011). İlginç bir şekilde, Lightdale ve Prentice (1994), saldırganlıkta cinsiyet farkl1lıklarının bireylerin kimliği anonimleştiğinde ortadan kalktığını belirtmektedirler. Gerçekleştirdikleri çalışmada, saldırganlık içeren video oyununda oyuncuların kimlik ve cinsiyet bilgilerinin bilindiği koşulda var olan cinsiyete dayalı saldırganlık düzeyi farklılığının, cinsiyet belirtilmediğinde yok olduğunu görmüşlerdir.

Biyolojik cinsiyetin mi yoksa toplumsal cinsiyetin mi saldırganlığ 1 daha iyi yordadığ 1 sorusuna yanıt aramak üzere yürütülen araştırmalar, Sosyal Rol Kuramının önermeleriyle tutarlı bir şekilde, toplumsal cinsiyetin daha güçlü bir etkiye sahip olduğunu göstermektedir (Archer, 2006). Kisaca, kadınlarla erkekler saldırganlık açısından biyolojik olarak eşit bir potansiyele sahipken, toplumlar erkeklerin bunu sergilemesini yüreklendirmekte, kadınlarınkini de yasaklayıp baskılamaktadır. Kadınlara yakıştırılan "duygusallık” ve "duygularını açığa vurma" niteliklerinin ilginç bir şekilde, daha önce de belirtildiği gibi, öfke duygusu için geçerli olmadığg vurgulanmaktadır. Erkek egemen bir toplumda yaşayan kadın öfkesini bastırmak zorunda kalmaktadır, bu da ruhsal ve bedensel boyutta önemli bir hasara yol açmaktadır. Kadının, özellikle erkeklere ve çocuklarına karşı öfke ve saldırganlıktan kaçınması salık verilmektedir. Geleneksel beklentilere göre, kadın, gerektiği zaman çocuklarını disipline etmeli, ancak kadın olduğunu unutmadan, sessiz ve duyarlı olmalı, öfkeden uzak durmalı ve çocuğuna bu yönde örnek olmalıdır. Bunu başaramayan kadın suçluluk duymalı ve değişmek için çaba harcamalıdır (Frost ve Averill,1982).

Erkeklerin saldırganlık eğilimlerinde cinsiyet rolü toplumsallaşmasının etkisi "maço kişilik örüntüsü” başlığı altında da işlenmektedir. Bu kavram yoluyla, erkeklerin saldırgan davranışları kendi içlerinde bireysel farklılıklarla açıklanmaya çalışılmaktadır. Maço kişilik örüntüsü, kadına yönelik duyarsız cinsel tutumlar, şiddeti erkekçe bir eğilim olarak algılama ve tehlikeyi heyecan verici bulma şeklinde siralayabileceğimiz üç farklı yapı barındirmaktadır (Krahe, 2011, s.63).

Saldırganlık erkeklerin toplumsal cinsiyet rollerinin içine derinden işlemiş olduğu için, maço erkeklerin aşırı erkeksi tarzda olmayan erkeklere kıyasla daha da saldırgan davranmaları beklenmektedir. Mosher ve Sirkin (1984), maço kişilik örüntüsünün dürtüsel davranma ve saldırganlıkla olumlu, anlayışlılık ve zarar vermekten kaçınma ile de olumsuz bir ilişkisi olduğunu ortaya koymuşlardır.

Sosyal Öğrenme Kuramı da sosyal rollerin saldırganlıkta cinsiyet farklılıklarındaki yerini yadsımamakta, ancak saldırgan davranışın içselleştirilmesi, kazanılması ve kalıcı hale gelmesinde daha çok öğrenme süreçlerinin önemini vurgulamaktadır. Bu süreçler (kültürel değerlerin anababa, akran grubu, eğitim sistemi, televizyon ve diğer kitle iletişim araçları yoluyla aktarılması) erkeklerin kadınlara kıyasla daha çok doğrudan saldırganlık sergiler hale gelmesi sonucunu doğurmaktadır (Bandura, 1973).

\section{Sonuç ve Tartışma}

Bir başkasına amaçlı olarak zarar verme niyetiyle sergilenen davranış olarak tanımlayabileceğimiz saldırganlık, kadınlarla erkekler arasındaki en temel farklilıklardan biri olarak kabul edilmektedir. Uzun yıllar boyunca, toplumsal cinsiyet kalıpyargılarını doğrular şekilde, erkeklerin kadınlardan daha saldırgan olduğunu belgeleyen birçok araştırma bulgusu ortaya konmuştur (Bettencourt ve Miller, 1996; Harris, 1996; Richardson, Vandenberg ve Humphries, 1986). Ancak, 1990'l1 yılların başlarında, saldırganlığın birçok farklı türünün olduğunun kabul edilmesiyle birlikte, aslında kadınların da erkekler kadar saldırgan olabileceği, tek farkın, fiziksel saldırganlık gibi doğrudan saldırganlık türleri yerine dolaylı saldırganlığı tercih etmeleri olduğu görülmüştür (Björkqvist ve Niemela, 1992; Crick ve Grotpeter, 1995; Galen ve Underwood, 1997; Lagerspetz, Björkqvist ve Peltonen, 1998).

Krahe (2011) yeni araştırmaların eskilere kıyasla gittikçe daha az cinsiyet farklılı̆̆ 1 ortaya koymaya başladığını ve bunun kimi araştırmacılar tarafından toplumsallaşmanın biyolojiye kıyasla daha güçlü bir belirleyici olduğunun kanıtı olarak değerlendirildiğini belirtmektedir. Ancak, bu yorum, 80'li yıllardan sonra yapılan araştırmaların geçmiş çalışmalardan yöntem ve ele aldıkları saldırganlık türleri açısından farklı olması gerçeğiyle değerini yitirmiştir. Bu yöntem farklılığ 1 dikkate alınarak yapılan meta-analiz çalışmaları saldırganlıkta cinsiyet farklılıklarının son yıllarda bir azalma göstermediğini ortaya koymaktadır. Bu farkın, aksine, özellikle dolayl1 saldırganlık kavramının gündeme geldiği dönemden bugüne farklı boyutlarda da varlık göstermeye başladığ 1 görülmektedir (Björkqvist, 1994).

Kadınlarla erkekler arasındaki farklılıkları evrimsel süreçlerle, biyolojiyle ve hormonlarla, sosyal öğrenmeyle ve sosyal rol dağılımıyla açıklayan birçok yaklaşım bulunmaktadır (Krahe, 2013). Özellikle, biyoloji ve hormonlara dayalı önermeleri destekleyen birçok bulgunun mevcut olduğu görülmektedir (Björkvist, 2018; Fussell, Rowe ve Park, 2011). Ancak, bu bulgulara ilişkin yorumlar tartışmalıdır. Kabul edilmelidir ki, biyolojik açıklamalar benimsendiği ölçüde, sadece saldırganlıkta değil, birçok alanda var olan cinsiyet fark- 
lılıklarının ve dolayısıyla cinsiyet eşitsizliğinin devam etmesini olağan karş1liyoruz demektir (Lindsey, 2011, s. 52). Aksine, toplumsal cinsiyet farklılıklarını ve cinsiyet eşitsizliğini açıklamak üzere yapılan sosyal öğrenmeye, sosyal rollere ve kültüre dayalı açıklamalar, bir şeylerin değişebileceği yönünde birer umut 1şı̆̆ıdır. Kaldı ki gözlemlenen cinsiyet farklılıklarının, biyolojik cinsiyetten (sex) ziyade toplumsal cinsiyetin (gender) etkisiyle gerçekleştiği görülmektedir. Else-Quest ve Hyde'ye göre (2018), bireylerin, araştırma ortamında (bir deney ortamında ya da ölçek doldururken) "kadın" ya da "erkek" olduklarını belirtmeleri bile üzerlerinde toplumsal cinsiyet normlarına uygun davranma yönünde bir bask1 oluşturabilmektedir. "Erkeklerin kadınlardan daha saldırgan davranmalarının beklendiğini” düşünen bir erkek ya da "kadınların erkeklerden daha az saldırgan olmalarının beklendiği”" kalıpyargısını içselleştiren bir kadın, bu beklentilere uygun davranmakta, böylece bu durum da araştırma sonuçlarını etkilemektedir.

Richardson ve Hammock (2007, s. 424), “cinsiyet saldırganlığın belirleyicisi ya da yordayıcısı mıdır?" sorusuna yanıt ararken, bu yanıtı bazı temel değişkenleri göz önünde bulundurarak vermek gerektiğini belirtmektedir. Bunları şu şekilde sıralamak mümkündür;

1. Saldırganlık ve cinsiyet ilişkisi sosyal bağlamdan bağımsız olarak değerlendirilemez.

2. Cinsiyet rolleri, cinsiyete kıyasla çok daha temel bir saldırganlık yordayıcısıdır. Sosyal Rol Kuramı temelinde öne sürülen bu hipotez birçok araştırmayla da desteklenmiştir

3. Cinsiyetle saldırganlık ilişkisi, saldırganlık türü temel alındığında, fiziksel saldırganlık açısından belirgindir.

4. Saldırganlıkta cinsiyet farklılıkları ilişkinin niteliği ve türü dikkate alınarak değerlendirilmelidir.

5. Kadınların dolaylı saldırganlık eğilimlerinin erkeklerinkinden çok az bir farkla fazla olduğu görülmektedir, ancak bu da büyük oranda bu eğilimin altında yatan güdülenmeyle ilişkili görünmektedir.

Sonuç olarak, cinsiyetin saldırganlığın bir belirleyicisi ya da yordayıcısı olup olmadığı sorusuna evet ya da hayır yanıtı vermek yerine, hangi koşullar altında hangi tür saldırganlık açısından ne tür bir güdülenmeyle bir farklılık gözlenebileceği üzerinde durmak, resmi bütün olarak görebilmek adına daha akılcı bir yaklaşım gibi görünmektedir.

Diğer yandan, erkeklerle kadınların saldırganlığa yükledikleri anlam, saldırganlık sergileme nedenleri arasındaki farklılıklar (altında yatan güdülenme) ve şiddete ilişkin tutumları da elbette gözlenen farklılıkların altında yatan temel etmenlerdendir. Bu nedenle bu cinsiyet farklılığı, sözü edilen konularda gerçekleştirilecek güncel çalışmalarla birlikte değerlendirilip irdelenmelidir.
Özellikle sosyal medyanın kullanımının yaygınlaşmasıyla birlikte gündeme gelen yeni saldırganlık türleri açısından (örn., siberzorbalık) cinsiyet farklılıkları olup olmadığ1 (örn., Wong, RCheung, \& Xiao, 2018) ve bu durumun gelişim evrelerine göre gösterdiği dalgalanma, üzerinde durulması gereken son derece güncel konulardır. Bunun yanında, genel olarak, kültürün insan davranışı üzerinde ne denli etkili olduğu açıktır. Her ne kadar meta-analiz çalışmaları sözü edilen farklılığın evrensel olduğu yönünde bulgular sunsa da, bu alanda güncel kültürlerarası çalışmaların (örn., Lansford, 2012) yapılması da büyük önem taşımaktadır.

Genel olarak bakıldığında, kadınlarla erkekler arasında var olan farklılıkların, büyük oranda, uygun davranışları tanımlayan reçeteler olan sosyal rollerin bir sonucu olduğunu söylemek yanlış olmayacaktır. Toplumsal cinsiyet rollerine ilişkin etiketlemeler ve bu yöndeki beklentiler, kadınlarla erkekler arasındaki saldırganlık eğiliminin temel belirleyicisi gibi görünmektedir. O halde, belki de bunu kırmanın yolu, toplumların, saldırganlık eğiliminin hem kadınsılıkla hem de erkeksilikle uyuşmayan bir nitelik olduğu vurgusunu yapmasından geçmektedir. Saldırganlığın ve şiddetin, herhangi bir cinsiyet ayrımı olmaksızın toplumsal cinsiyet kalıpyargılarından ve rol beklentilerinden çıkarıldığ 1 "ideal" durum, bu farklılığ da büyük ölçüde ortadan kaldıracak gibi görünmektedir. 


\section{Kaynaklar}

Archer, J. (2010). What is indirect aggression in adults? K. Österman (Ed.), Indirect and direct aggression (s. 3-16), Frankfurt \& Berlin: Peter Lang.

Archer, J. ve Coyne, S. M. (2005). An integrated review of indirect, relational, and social aggression. Personality and Social Psychology Review, 9(3), 212-230

Archer, J. ve Lloyd, B. (2002). Sex and gender. Cambridge: Cambridge University Press.

Archer, J. (1991). The influence of testosterone on human aggression. British Journal of Psychology, 82, 1-28.

Archer, J. (1992). Childhood gender roles: Social context and organisation. H. McGurk (Ed.) Childhood social development: Contemporary perspectives, (s. 31 - 61). Erlbaum.

Archer, J. (2000). Sex differences in physical aggression to partners: A reply to Frieze (2000), O'Leary (2000), and White, Smith, Koss, and Figueredo (2000). Psychological Bulletin, 126(5), 697-702.

Archer, J. (2004). Sex differences in aggression in real-world settings: A meta-analytic review. Review of General Psychology, 8, 291 - 322.

Archer, J. (2006). Cross-cultural differences in physical aggression partners: A social- role analysis. Personality and Social Psychology Review, 10, 133-153.

Archer, J. (2009). The nature of human aggression. International Journal of Law and Psychiatry,32, 202-208.

Archer, J. ve Cote, S. (2005). Sex differences in aggressive behavior: A developmental perspective. R. E. Tremblay, W. W. Hartup ve J. Archer (Ed.), Developmental origins of aggression içinde (425-443). New York: Guilford.

Archer, J., Holloway. R. ve McLoughlin, K. (1995). Self-reported physical aggression among young men. Aggressive Behavior, 21, 325-342

Bailey A. A. ve Hurd, P. L. (2005). Finger length ratio (2D:4D) correlates with physical aggression in men but not in women. Biological Psychology, 68, 215-222.

Baillargeon, R. H. , Zoccolillo, M., Keenan, K. ve ark. (2007). Gender differences in physical aggression: A prospective population-based survey of children before and after 2 years of age. Developmental Psychology, 43(1), 13-26.

Bandura, A. (1973). Aggression: A social learning analysis. Oxford, England: Prentice-Hall

Bandura, A. (1978). Social learning theory of aggression. Journal of Communication, 28(1), 12-29.
Begley, S. (2009). Pink brain, blue brain: Claims of sex differences fall apart. Newsweek, September 14, 28.

Bettencourt, B. A. ve Miller, N. (1996). Gender differences in aggression as a function of provocation: A meta-analysis. Psychological Bulletin, 119, 422-447.

Björkqvist, K. (2018). Gender differences in aggression. Current Opinion in Psychology, 19, 39-42.

Björkqvist, K. (1994). Sex differences in physical, verbal, and indirect aggression: A Review of Recent Research. Sex Roles 30(3/4), 177-88.

Björkqvist, K. ve Niemela, P. (1992). New trends in the study of female aggression. K. Björkqvist ve P. Niemela (Ed.), Of mice and women: Aspects of female aggression içinde (3-15). London: Academic Press.

Book, A. S., Starzyk, K. B. ve Quinsey, V. L. (2001). The relationship between testosterone and aggression: a meta-analysis. Aggression and Violent Behavior, 6, 579-599.

Booth, A. ve Dabbs, J. M. Jr (1993) Testosterone and men's marriages. Social Forces, 72, 463-477.

Broidy, L.M., Nagin, D.S., Tremblay, R.E., Bates, J.E., Brame, B., Dodge, K.A., ... ve Vitaro, F. (2003). Developmental trajectories of childhood disruptive behaviors and adolescent delinquency: A six-site, cross-national study. Developmental Psychology, 39, 222-245.

Cairns, R. B. ve Cairns, B. D. , Neckerman H. J. ve ark. (1989). Growth and aggression: Childhood to early adolescence. Developmental Psychology, 25(2), 320-330.

Card, N. A. ve Little, T. D. (2006). Proactive and reactive aggression in childhood and adolescence: a meta-analysis of differential relations with psychosocial adjustment. International Journal of Behavioral Development, 30, 466-480.

Crick, N. ve Grotpeter, J. (1995). Relational aggression, gender, and social-psychological adjustment. Child Development, 66, 710-722.

Cote, S. M. (2007). Sex Differences in Physical and Indirect Aggression: A Developmental Perspective. European Journal on Criminal Policy and Research 13(3):183-200

Daly, M. ve Wilson, M. (1994). Evolutionary psychology of male violence, J. Archer (Ed.), Male violence (s. 253-288). Routledge

Darwin, C. (1871). The descent of man and selection in relation to sex. Murray, London.

Eagly, A. H. (1983). Gender and social influence: A social psychological analysis. American Psychologist, 38(9), 971-981. 
Eagly, A. H. (1987). Sex differences in social behavior: A social role interpretation. Hillsdale, $\mathrm{NJ}$ : Erlbaum

Eagly, A. H. , Wood, W. ve Diekman, A. B. (2000). Social role theory of sex differences and similarities: A current appraisal. T. Eckes and H. M. Trautner (Ed.), The developmental social psychology of gender içinde (123-174). Mahwah, NJ: Lawrence Erlbaum

Eagly, A. H. ve Crowley, M. (1986). Gender and helping behavior: A meta-analytic review of the social psychological literature. Psychological Bulletin, 100(3), 283-308.

Eisner, M. P. ve Malti, T. (2015). Aggressive and violent behavior, Handbook of child psychology and developmental science (7. Bask1). M. E. Lamb ve R. M. Lerner (Ed.), Social emotional and personality development, Cilt 8, Vol 3 içinde (795-884). New York: Wiley.

Eagly, A. H. ve Steffen, V. J. (1986). Gender and aggressive behavior: A meta-analytic review of the social psychological literature. Psychological Bulletin, 100(3), 309-330.

Elias, M. (1981). Serum cortisol, testosterone, and testosterone binding globulin responses to competitive fighting in human males. Aggressive Behavior, 7, 215-224.

Else-Quest, N. M. ve Hyde, J. S. (2018). The psychology of women and gender. $9^{\text {th }}$ edition. LA:Sage.

Fine, C. (2011). Delusions of gender: The real science behind sex differences. New York, NY: W. W. Norton.

Frost W. D. ve Averill J.R. (1982) Differences between men and women in the everyday experience of anger. Anger and Aggression, Springer Series in Social Psychology, NY: Springer.

Fussell, N. J., Rowe, A. C. ve Park, J. H. (2011). Masculinised brain and romantic jealousy: Examining the association between digit ratio (2D: 4D) and between-and within-sex differences. Personality and Individual Differences, 51(2), 107-111.

Galen, B. R. ve Underwood, M. K. (1997). A developmental investigation of social aggression among children. Developmental Psychology, 33(4), 589600

Gendreau, P. ve Archer, J. (2005). Subtypes of aggression in humans and animals. R. Tremblay, W. Hartup, ve J. Archer (Ed.), The developmental origins of aggression içinde (25-46), New York: Guilford Press

Halpern, C., Udry, R., Campbell B. ve Suchindran, C. (1993). Relationships between aggression and pubertal increases in testosterone: A panel analysis of adolescent males. Social Biology. 40(1-2), 8-24.
Hamby, S. L. ve Sugarman, D. B. (1999). Acts of psychological aggression against a partner and their relation to physical assault and gender. Journal of Marriage and Family, 61(4), 959-970.

Hammock, G. ve O'Hearn, R. (2002). Psychological aggression in dating relationships: Predictive models for males and females. Violence and Victims, 17(5), 525-40.

Harris, M. B. (1996). Aggression, gender, and ethnicity. Aggression and Violent Behaviour, 1, 123-146.

Hay, D. F., Castle, J. ve Davies, L. (2000). Toddlers' use of force against familiar peers: A precursor of serious aggression? Child Development, 71(2), 457-467.

Hess, N.H ve Hagen, E. H., (2006). Sex differences in indirect aggression. Evolution \& Human Behavior, 27(3), 231-245.

Huesmann, L. R. ve Guerra, N. G. (1997). Children's normative beliefs about aggression and aggressive behavior. Journal of Personality and Social Psychology, 72(2), 408-419

Hyde, J. S. (2005). The gender similarities hypothesis. American Psychologist, 60(6), 581-592.

Jezl, D. R., Molidor, C. E. ve Wright, T. L. (1996). Physical, sexual and psychological abuse in high school dating relationships: Prevalence rates and self-esteem issues. Child and Adolescent Social Work Journal, 13(1), 69-87.

Kasian, M. ve Painter, S. L. (1992). Frequency and severity of psychological abuse in a dating population. Journal of Interpersonal Violence, 7, 350-364

Krahe, B. (2013). The social psychology of aggression. $2^{\text {nd }}$ edition. London: Psychology Press.

Krahe, B. (2011). The social psychology of aggression. East Sussex, England: Psychology Press.

Lagerspetz, K. M. J., Björkqvist, K. ve Peltonen, T. (1988). Is indirect aggression typical of females? Gender differences in aggressiveness in 11- to 12-year-old children. Aggressive Behavior, 14, 403-414.

Lansford, J. E., Skinner, A. T., Sorbring, E., Giunta, L. D., Deater-Deckard, K., Dodge, K. A., ... Chang, L., ( 2012). Boys' and girls' relational and physical aggression in nine countries. Aggressive behavior, 38, 298-308.

LaPrairie, J. L., Schechter, J. C., Robinson, B. A. ve Brenn, P. A. (2011). Perinatal risk factors in the development of aggression and violence, Advances in Genetics, 75, 215-253.

Lightdale, J. R. ve Prentice, D. A. (1994). Rethinking sex differences in aggression: Aggressive behaviour in the absence of social roles. Personality and Social Psychology Bulletin, 20, 34-44. 
Lindsey, L. L. (2011). Gender roles: A sociological perspective (5th ed.). Upper Saddle River, NJ: Prentice Hall.

Lipsey, M. ve Derzon, J. H. (1998). Predictors of violent or serious delinquency in adolescence and early adulthood. R. Loeber, \& D. P. Farrington (Eds.), Serious and violent juvenil offenders, (s. 86-105). Thousand Oaks, CA: Sage.

Maccoby, E. E. ve Jacklin, C. N. (1980). Sex differences in aggression: A rejoinder and reprise. Child Development, 51(4), 964-998.

Marcus, R. F. (2017). The development of aggression and violence in adolescence. NY. Palgrave Macmillan.

Marshall, L. L. (1994). Physical and psychological abuse. W. R. Cupach ve B. H. Spitzberg (Ed.), LEA's communication series. The dark side of interpersonal communication içinde (281-311). Hillsdale, NJ, US: Lawrence Erlbaum Associates, Inc.

Mazur, A. (2009). Testosterone and violence among young men. A. Walsh \& K. M. Beaver (Ed.), Biosocial criminology: New directions in theory and research içinde (190-204). NY: Routledge.

Mazur, A., Booth, A. ve Dabbs, J. M. Jr (1992). Testosterone and chess competition. Social Psychological Quarterly, 55, 70-77.

Miczek, K. A., Mirsky, A. F., Carey, G., DeBold, J. ve Raine, A. (1994). An overview of biological influences on violent behavior . A. Reiss, K. A. Mİczeck ve J. Roth (Ed.), Understanding and preventing violence: Vol. 2. Biobehavioral Influences içinde (1-20). Washington DC: National Academy Press.

Molidor, C. E. (1995). Gender differences of psychological abuse in high school dating relationships. Child and Adolescent Social Work Journal, 12, 119-134

Mosher, D.L. ve Sirkin M. (1984). Measuring a macho personality constellation. Journal of Research on Personality, 18, 150-163.

Österman, K., Björkqvist, K., Lagerspetz, K. M. J., Kaukiainen, A., Landau, F., Fraczek, A. ve ark. (1998). Cross-cultural evidence of female indirect aggression. Aggressive Behavior, 24, 1-8.

Owens, L., Shute, R. ve Slee, P. (2000). 'Guess what I just heard!': Indirect aggression among teenage girls in Australia. Aggressive Behavior, 26, 67-83.

Petersen, J. L., ve Hyde, J. S. (2010). A meta-analytic review of research on gender differences in sexuality, 1993-2007. Psychological Bulletin, 136, 21-38.

Polaschek, D.L.L., Collie, R. M. ve Walkey, F. H. (2004), Criminal attitudes to violence: Development and preliminary validation of a scale for male prisoners. Aggressive Behavior, 30, 484-503. doi:10.1002/ab.20081
Reinisch, J. M. ve Sanders, S. A. (1992). Effects of prenatal exposure to diethylstilbestrol (DES) on hemispheric laterality and spatial ability in human males. Hormones and Behavior, 26, 62-75.

Richardson D. S. ve Hammock, G. S. (2011). Is it aggression? Perceptions of and motivations for passive and psychological aggression. J. P. Forgas, A. W. Kruglanski, K. D. Williams (Ed.), The Psychology of Conflict and Aggression içinde (53-65). NY: Psychology Press.

Richardson, D. R., Vandenberg, R. J. ve Humphries, S. A. (1986). Effect of power to harm on retaliative aggression among males and females. Journal of Research in Personality, 20, 402-419.

Richardson, D.R., Green, L. R. (1999). Social sanction and threat explanations of gender effects on direct and indirect aggression. Aggressive Behavior, 25, 425-434.

Richardson, D.S. ve Hammock G.S. (2007). Social context of human aggression: Are we paying too much attention to gender? Aggression and Violent Behavior, 12, 417-426.

Richardson, D. S. ve Green, L. R. (2006). Direct and indirect aggression: Relationships as social Context. Journal of Applied Social Psychology, 36, 24922508.

Shaffer, D. R. (2009). Social and personality development, 6th ed. Wadsworth: Cengage Learning.

Smith, R. L., Rose, A. J. ve Schwartz-Mette, R. A. (2009). Relational and overt aggression in childhood and adolescence: clarifying mean-level gender differences and associations with peer acceptance. Social Development, 19(2), 243-269.

Snethen, G. ve Van Puymbroeck, M. (2008). Girls and physical aggression: Causes, trends, and intervention guided by Social Learning Theory. Aggression and Violent Behavior, 13, 346-354.

Stets, J. E. (1991). Psychological aggression in dating relationships: The role of interpersonal control. Journal of Family Violence, 6(1), 97-114.

Tackett, J. L., Waldeman I. D. ve Lahey B. B. (2009). Etiology and measurement of relational aggression: a multi-informant behavior genetic investigation. Journal of Abnormal Psychology, 118, 722-733.

Tremblay, R. E. ve Nagin, D. S. (2005). The developmental origins of physical aggression in humans. R. E. Tremblay, W. W. Hartup, J. Archer (Ed.), Developmental Orijins of Aggression içinde (83-107). NY: Guilford Press.

Trivers, R. L. (1972). Parental investment and sexual selection. B. Campbell (Ed.), Sexual selection and the descent of man: 1871-1971 içinde (136-179). Chicago: Aldine. 
Vaillancourt T., Miller J. M. ve Sharma A. (2010). Tripping the prom queen: female intrasexual competition and indirect aggression. K. Osterman (Ed.), Indirect and Direct Aggression, içinde (7-31). Frankfurt: Peter Lang.

Vaillancourt, T. ve Krems, J. A. (2018). An evolutionary psychological perspective of indirect aggression in girls and women. S. M. Joyne ve J. M. Ostrov (Ed.), The development of relational aggression içinde (111-127). NY. Oxford University Press.

Vaillancourt, T. (2013). Do human females use indirect aggression as an intrasexual competition strategy? Philosophical Transactions of the Royal Society B, Biological Sciences. 368, 20130080.

Van Goozen, S. H. M.(2005). Hormones and the developmental origins of aggression. R. E. Tremblay, W. W. Hartup ve J. Archer (Ed.), Developmental Origins of Aggression içinde (281-306). New York: Guilford Press.

Weaver, J.R., Vandello, J.A., Bosson, J.K. ve Burnaford, R.M. (2010). The proof is in the punch: Gender differences in perceptions of action and aggression as components of manhood Sex Roles, 62, 241-251.

Werner, N. E. ve Crick, N. R. (2004). Maladaptive peer relationships and the development of relational and physical aggression during middle childhood. Social

Wong, R. Y. M., Cheung, C.M.K. ve Xiao, B. (2018). Does gender matter in cyberbullying perpetration? An empirical investigation. Computers in Human Behavior, 79, 247-257.

Wood, W. ve Eagly, A. H. (2002). A cross-cultural analysis of the behavior of women and men: Implications for the origins of sex differences. Psychological Bulletin, 128(5), 699-727.

Zell, E., Krizan, Z. ve Teeter, S. R. (2015). Evaluating gender similarities and differences using metasynthesis. American Psychologist, 70, 10-20. 


\title{
Summary \\ Gender Differences in Aggression: A Current Review of Empirical and Theoretical Studies
}

\author{
H. Andaç Demirtaş-Madran \\ Başkent University
}

Aggression could be defined as a behaviour that is expressed with intent to harm, injure, or exploit another person. Aggression is a dynamic, multi-faceted phenomenon that is important from an individual, social and universal point of view, which needs to be elaborated in terms of causes, consequences, determinants, and forms of exhibition. Numerous researchers from different disciplines such as psychology, anthropology, psychiatry, biology, etiology, health sciences, genetics, education, law, and sports sciences have been carried out studies on the relationship between aggression and many variables.

Gender is the most researched variable in the relationship with aggression. Although the universal stereotype of "men are more aggressive (especially physically) than women" has been confirmed by many studies, it is clear that the relationship between the two variables is not so simple. In this review, the relationship between gender and aggression will be examined based on current researches and meta-analysis. At first, the definitions and classifications of aggression will be emphasized. Then, the relationship between the two variables will be analyzed in light of current research findings. Finally, these findings will be evaluated and discussed within the main theoretical perspectives.

In recent years, it's seen that gender studies are mainly focused on gender similarities rather than gender differences ((Else-Quest and Hyde, 2018). According to Else-Quest and Hyde (2018), there are more similarities between women and men than differences. The few gender differences supported in their research can be listed as follows; men have more positive attitudes toward casual sexual intimacy, they have higher levels of physical aggression than women and masturbate more than women.

For a long time, research findings revealed that gender is the main predictor of aggression and violence, confirming gender stereotypes. However, aside from all these research results, with the introduction of the term "indirect aggression" into the literature, it is seen that the findings began to differentiate. Thus, the belief that "women are less aggressive than men" has been replaced by the view that "women show different types of aggression" (Björkqvist, 2018).

According to Björkqvist (1994), there are three forms of aggressive behaviour: direct physical aggression, direct verbal aggression, and indirect aggression. Indirect aggression is a form of social manipulation to harm the victim, as through gossip or manipulating his/her social network, excluding him/her from social groups. Males show more physical aggression than females and females show more indirect and relational aggression than males.

Card and Little (2006) conducted a meta-analysis study including 148 studies on direct and indirect aggression in childhood and adolescence, and, as expected, found that boys had a higher tendency to direct aggression and girls (with only a small difference) tendency to indirect aggression. These differences appear to be a constant, common finding in all studies regardless of the method used (Card and Little, 2006). Another important finding of gender differences in aggression (especially in physical aggression) is the rapid increase occurs in adolescence and young adulthood (Archer, 2009). This can be explained by the relationship between indirect aggression and cognitive development. Österman et al. (1998) found that an 8-year-old child could also exhibit indirect aggression, but 15 years-old girls can develop a more complex strategy for indirect aggression than younger children.

On the other hand, research showed that when questioning the relationship between gender and aggression, it is necessary to take into consideration the fact that the answer will vary according to "the type of relationship between the target and the source (actor and

Address for Correspondence: Prof. Dr. H. Andaç Demirtaş-Madran, Başkent University, Faculty of Communication, Campus of Bağlıca, Fatih Sultan Neighborhood Eskișehir way 18.km 06790 Etimesgut / Ankara

E-mail: andac@baskent.edu.tr 
victim)", "the type of aggression" as well as the "gender of the target".

There are major theories that attempt to explain the relationship between aggression and gender. Based on the literature it is seen that the efforts to explain the relationship between the two variables are mostly based on the genetic and evolutionary, biological, social learning, and social role theories.

Evolutionary psychologists argue that societies where men are physically stronger, aggressive, and brave, and women are fertile and caring, prevail over the natural selection process (Fine, 2011). According to this approach, biological structures of men and women have evolved; this is manifested by the fact that men are brash, brave, and prone to violence and women are more brittle, graceful, maternal, and nutritious by nature.

Archer (1991) conducted three separate meta-analysis studies and concluded that there is a weak positive relationship between aggression and testosterone levels. In a meta-analysis of forty-five studies, Book et al. (2001) also found that this weak positive relationship. Another hormone thought to be associated with aggression in men is cortisol. Similarly, oxytocin, which is thought to be associated with trust and proximity, is associated with aggression, and if this hormone is low, an increase in aggressive tendencies is observed. However, the findings of studies dealing with the relationship between both hormones and aggression are quite contradictory (LaPraririe, Schechter, Robinson, \& Brenn, 2011).

On the other hand, it is claimed that the prenatal hormonal environment is the most important determinant of gender differences in behaviour (eg, Björkvist, 2018; Fussell, Rowe, and Park, 2011). The 2D: 4D finger ratio (ratio between the length of the index finger and the ring finger) is reported to be related to the hormones exposed in the womb. It is suggested that there is a high positive relationship between physical aggression tendency and low 2D: 4D in men (Bailey and Hurd, 2005). Van Goozen (2005) states that the effects of biological and hormonal factors on human behaviour should not be evaluated as "deterministic". The environment and culture can transform biological behaviour by rewarding, punishing, ignoring, reducing, and increasing the frequency of the behaviour (Reinisch and Sanders, 1992).

According to social learning theory, aggression is learned from parents, other authority figures, peers, and media through observation, modeling, imitation, rewarding, and reinforcing (Bandura, 1978). This theoretical perspective focuses on the factors that initiate, trigger, and sustain aggression in humans (Snethen and Puymbroeck, 2008). From this point of view, it would be more appropriate to consider gender differences in aggression as gender differences in the validation of aggression
(Huesmann and Guerra, 1997, p. 409). Modeling plays a fundamental role in learning aggression. Observation allows the individual not only to learn the modeled behaviour but also to produce and display more innovative versions of this behaviour. Thus, we can explain that physical aggression levels of men and indirect aggression levels of women are higher than the opposite sex, not by genetics, but by modeling and identifying parents of the same sex. On the other hand, according to Social Role Theory, as in all social behaviours, gender differences in aggression are based on the roles of men and women (women work at home, men work outside the home) (Eagly, 1987).

Eagly et al. (Eagly and Crowley, 1986; Wood and Eagly, 2002) argue that gender-related social roles guide aggressive behaviour. Therefore, gender differences in aggression can be considered as a result of the relationship between aggression and socialization (Richardson and Hammock, 2007, p. 418). Many researchers argue that aggression is learned in the socialization process as an extension of the masculine gender role orientation. According to Eagly (1987), in the process of gender role socialization, aggressive tendencies of boys are supported and girls are restricted.

On the other hand, the meaning attributed to aggression by men and women, the differences between the reasons for displaying aggression (underlying motivation), and their attitudes towards violence were, of course, the main underlying factors of the observed differences in aggression. For this reason, these differences should be evaluated and examined together with the current studies on the mentioned subjects. Whether there are gender differences in terms of new types of aggression (eg., cyberbullying), especially with the widespread use of social media, and the fluctuation of this situation according to the stages of development are highly up-todate issues that need to be addressed.

Besides, in general, it is clear the effective role of the culture is on human behaviour. Although meta-analysis studies provide evidence that this difference is universal, it is of utmost importance to carry out contemporary intercultural studies in this area.

In general, it would not be wrong to say that the differences between men and women are largely the result of the social roles, which are prescriptions describing appropriate behaviour. The gender stereotypes and expectations of gender roles appear to be the main determinants of the aggression tendency between men and women. So perhaps the way to break this it is important to emphasize that the tendency of aggression is incompatible with both femininity and masculinity. The "ideal" situation in which aggression and violence are subtracted from gender stereotypes and gender role expectations 
without any gender discrimination seems to eliminate this difference to a large extent.

As a result, instead of answering "yes" or "no" to the question of whether gender is a determinant or predictor of aggression, considering the picture as a whole; under which circumstances, which type of aggression may differ from what kind of motivation, is a more. 